\title{
Workplace Spirituality Ditinjau dari Aspek Demografi: Jenis Kelamin, Tingkat Pendidikan, dan Lama Bekerja di Organisasi
}

\author{
Kitara Harumi $^{1}$, Yus Nugraha ${ }^{2}$, Anissa Lestari Kadiyono ${ }^{3}$ \\ ${ }^{1}$ Program Studi Psikologi Universitas Padjadjaran \\ ${ }^{1}$ kitara18001@mail.unpad.ac.id
}

\begin{abstract}
Workplace spirituality is becoming a topic that start to gain attention for organization. Workplace spirituality is the recognition that employees have an inner life that nourishes and is nourished by meaningful work that takes place within the context of a community. Workplace spirituality has three dimensions consist of inner life, meaning and purpose in work, dan a sense of connection and community. The purpose of this study is to examine the difference of workplace spirituality in terms of sex, education, and years of experience at organization. The sample of this study was 81 employees who worked in an organization or company for at least one year. The instrument used for this research is The Meaning and Purpose at Work Questionnaire which has been adapted to the context of Indonesian culture. Data were analyzed using t-test and Kruskal-Wallis. The result showed that there is a significant difference of workplace spirituality in terms of years of experience at organization, with $p=0,003(p<0,05)$. This shows that years of experience at organization has more meaning in the workplace spirituality than gender and education level because employees who work longer in an organization will feel the connection between organizational values and personal values that can be the basis in meeting the spiritual needs of individuals.
\end{abstract}

Key words: workplace spirituality, sex, education, organization

\begin{abstract}
Abstrak
Workplace spirituality merupakan sebuah topik yang sedang menjadi perhatian di dunia organisasi. Workplace spirituality adalah pengakuan bahwa karyawan memiliki inner life yang terpelihara dan dipelihara oleh pekerjaan yang bermakna dalam konteks komunitas. Workplace spirituality memiliki tiga dimensi yaitu inner life, meaning and purpose in work, dan a sense of connection and community. Tujuan dari penelitian ini adalah untuk mengkaji perbedaan workplace spirituality ditinjau dari aspek demografi meliputi: jenis kelamin, tingkat pendidikan, dan lama bekerja di organisasi. Sampel penelitian adalah 81 orang karyawan yang telah bekerja pada sebuah organisasi atau perusahaan selama minimal satu tahun. Alat ukur yang digunakan adalah The Meaning and Purpose at Work Questionnaire yang telah di adaptasi ke dalam konteks budaya Indonesia. Analisis yang digunakan adalah t-test dan uji Kruskal-Wallis. Hasil uji hipotesis menunjukkan bahwa terdapat perbedaan workplace spirituality ditinjau dari lama karyawan bekerja di organisasi, sedangkan bila ditinjau dari jenis kelamin dan
\end{abstract}


tingkat pendidikan tidak terdapat pebedaan workplace spirituality. Hal ini menunjukkan bahwa lamanya karyawan bekerja pada sebuah organisasi lebih memiliki makna pada workplace spirituality dibandingkan jenis kelamin dan tingkat pendidikan karena karyawan yang memiliki masa kerja lebih lama pada sebuah organisasi akan merasakan keselarasan antara nilai organisasi dengan nilai pribadi karyawan yang dapat menjadi dasar dalam pemenuhan kebutuhan spiritual individu.

Kata kunci: workplace spirituality, jenis kelamin, tingkat pendidikan, organisasi

\section{Pendahuluan}

Organisasi terdiri dari orang-orang yang berinteraksi satu sama lain untuk menjalankan fungsi-fungsi penting di dalam organisasi demi mencapai sebuah tujuan tertentu (Daft, 2008). Dalam menghadapi perkembangan yang terjadi secara cepat di era Revolusi Industri 4.0, sebuah organisasi perlu untuk dapat mempertahankan kestabilan performa organisasi dengan berbagai cara, salah satunya adalah dengan mengelola salah satu faktor penting dalam menjalankan aktivitas organisasi yaitu Sumber Daya Manusia. Pada saat ini, salah satu perkembangan di dunia organisasi yang mulai menarik perhatian manajemen organisasi adalah dengan melibatkan aspek spiritualitas dalam upaya organisasi memelihara kesejahteraan karyawannya.

Spiritualitas merupakan bagian dari jiwa manusia yang melekat dan tidak dapat dipisahkan dari diri individu. Spiritualitas tidak melibatkan makna religius dan lebih mencakup kepada pengertian mengenai makna (meaning), tujuan (purpose), serta keterhubungan dengan pihak lain (being connected to others). Konsep spiritualitas telah diperluas dan diterapkan pada lingkup profesional dan organisasi. Pada lingkungan organisasi, spiritualitas memiliki aspek universal atau karakteristik yang ditemukan pada budaya dan organisasi yang berbeda. Karakteristik inilah yang menjadi inti dari spiritualitas dalam organisasi (Tecchio, Cunha, \& Santos, 2016). Spiritualitas melibatkan upaya untuk mencari tujuan dalam kehidupan melalui pengembangan relasi dengan rekan kerja, dan kepercayaan atas nilai organisasi (Mitroff \& Denton, 1999).

Spiritualitas di tempat kerja atau workplace spirituality, memberikan perhatian terhadap aspek spiritualitas karyawan. Konsep ini menyatakan bahwa 
karyawan sebagai makhluk spiritual, memiliki inner life atau kebutuhan untuk dipelihara jiwanya di tempat kerja. Hal ini terkait dengan makna dan rasa tujuan yang mereka rasakan pada pekerjaan mereka (meaning and purpose in work) serta rasa keterhubungan antara satu sama lain (a sense of connection and community). Ashmos \& Duchon (2000) menetapkan tiga dimensi tersebut sebagai dasar dari terbentuknya workplace spirituality.

Pada dimensi pertama, untuk dapat memahami workplace spirituality dapat dimulai dengan mengakui bahwa individu memiliki inner life dan outer life, yang apabila inner life seseorang dapat dipenuhi maka akan dapat mengarah pada outer life yang lebih produktif dan bermakna (Fox, 1994: Ashmos \& Duchon, 2000). Inner life melibatkan perasaan individu mengenai makna tentang siapa mereka serta kontribusi apa yang telah mereka berikan (Vaill, 1998: Duchon \& Plowman, 2005). Dimensi ini disebut sebagai elemen spiritual dasar dari individu. Untuk memahami inner life, perlu untuk memahami bagaimana sesorang dapat menggunakan kekuatan (divine power) yang dimiliki untuk dapat berfungsi secara penuh dalam kehidupannya sehingga individu dapat mencapai kehidupan yang memuaskan.

Dimensi kedua yaitu meaning and purpose in work menekankan bahwa dalam bekerja, karyawan juga mencari makna terhadap kehidupan mereka. Melalui pekerjaannya, karyawan ingin untuk merasa 'terhubung' dengan hal-hal yang dipandang oleh karyawan sebagai hal yang penting dalam kehidupan, sehingga pekerjaannya dapat menciptakan rasa suka cita yang menjadi dasar bagi karyawan untuk merasakan bahwa pekerjaannya dapat memberikan makna terhadap hidupnya. (Giacalone \& Jurkiewicz, 2003: Duchon \& Plowman, 2005).

Dimensi terakhir yaitu a sense of connection and community merupakan elemen penting dari perkembangan spiritual karyawan. Karyawan tidak hanya mengekspresikan inner life-nya dengan mencari makna pada pekerjaannya, tapi juga melibatkan bagian hidup lain yaitu kehidupan yang berhubungan dengan manusia lain(Ashmos \& Duchon, 2000). Tempat bekerja telah diakui sebagai komunitas tersendiri bagi karyawannya dan pekerjaan yang dilakukan merupakan sumber dari pertumbuhan spiritual serta keterhubungan dengan pihak lain. 
Karyawan ingin untuk merasa terhubung dengan pekerjaan yang penting dan karyawan ingin untuk berhubungan dengan rekan kerjanya satu sama lain.

Dengan menyadari keberadaan workplace spirituality, berarti organisasi mengakui bahwa dalam bekerja karyawan membawa keseluruhan dirinya yang mencakup pikiran, bakat, serta jiwa mereka yang unik (Tecchio et al., 2016). Organisasi yang memperhatikan aspek spiritualitas dinilai dapat mencapai performa kerja organisasi yang lebih tinggi, meningkatnya komitmen organisasi, kepuasan kerja, serta rendahnya turnover (Duchon \& Plowman, 2005; Milliman, Czaplewski, \& Ferguson, 2003). Karyawan yang merasakan bahwa dirinya menjadi bagian dari sebuah komunitas kerja, dapat membantu karyawan lain ketika menghadapi situasi yang sulit di masa depan. Lingkungan kerja yang menerapkan budaya saling berbagi dan memperhatikan satu sama lain juga dapat membuat karyawan menjadi lebih kreatif dan memiliki semangat juang, yang merupakan faktor penentu bagi organisasi untuk dapat mencapai performa organisasi yang baik. (Jean \& Garcia, 2003). Secara lebih lanjut dijelaskan bahwa workplace spirituality dapat mendorong karyawan untuk memberikan sikap kerja yang lebih positif dan memberikan pengaruh yang potensial terhadap beberapa perilaku organisasi yang dapat meningkatkan performa organisasi (Houghton, Neck, \& Krishnakumar, 2016).

Di Indonesia, belum banyak penelitian yang dilakukan terkait dengan workplace spirituality. Berdasarkan dari penelitian yang telah dilakukan, workplace spirituality dinyatakan berkontribusi secara signifikan terhadap dimensi dari organization citizenship behavior yaitu civic virtue (Widyarini, dalam Yogatama \& Widyarini, 2015). Selain itu workplace spirituality juga dinilai memiliki kontribusi terhadap motivasi intrinsik karyawan terutama pada aspek penegakan nilai (Yogatama, dalam Yogatama dan Widyarini, 2015). Belum ditemukan kajian mengenai workplace spirituality khususnya untuk melihat workplace spirituality pada karyawan di Indonesia yang ditinjau berdasarkan jenis kelamin karyawan, lama bekerja di organisasi, serta tingkat pendidikan karyawan.

Berdasarkan penjelasan diatas, dapat dilihat berbagai dampak positif yang dapat diberikan oleh workplace spirituality pada organisasi dan dengan 
mempertimbangkan bahwa belum banyak kajian yang dilakukan di Indonesia mengenai workplace spirituality, maka hal ini menjadi menarik dan penting untuk diteliti secara lebih jauh. Penelitian ini bertujuan untuk mengkaji perbedaan workplace spirituality berdasarkan jenis kelamin karyawan, lama bekerja di organisasi, serta tingkat pendidikan karyawan. Penelitian ini diharapkan dapat menambah kajian teoritis bagi peneliti lain yang memiliki ketertarikan dengan konsep workplace spirituality.

\section{Metode}

Pendekatan deskriptif kuantitatif dilakukan dalam penelitian ini. Dalam penelitian deskriptif, digunakan suatu prosedur ilmiah untuk menjawab permasalahan secara aktual, guna menjelaskan suatu fenomena yang terjadi (Sugiyono, 2015). Penelitian ini juga menggunakan uji beda dalam menganalisa data terkait dengan workplace spirituality.

\section{Sampel}

Kriteria yang digunakan untuk populasi dalam penelitian ini adalah: karyawan yang bekerja pada sebuah organisasi atau perusahaan (institusi negara, BUMN, maupun swasta) dan telah bekerja selama minimal 12 bulan (1 tahun). Roscoe (dalam Sugiyono, 2015) menyatakan bahwa dalam sebuah penelitian, ukuran sampel yang layak berada diantara 30 sampai dengan 500 subjek. Dalam penelitian ini, jumlah subjek yang berpartisipasi adalah sebanyak 81 subjek, yang terbagi menjadi 61 karyawan perempuan dan 20 karyawan laki-laki. Teknik sampling yang digunakan untuk memilih sample adalah teknik quota sampling.

\section{Teknik Pengumpulan Data}

Penelitian ini menggunakan instrumen The Meaning and Purpose at Work Questionnaire, yaitu kuesioner untuk mengukur nilai workplace spirituality pada level individu. Kuesioner ini disusun berdasarkan aspek-aspek yang dikembangkan oleh Ashmos \& Duchon (2000), yaitu 1) inner life, 2) meaning and purpose in work, dan 3) a sense of connection and community. Reliabilitas alat ukur diukur menggunakan Cronbach's alpha $(\alpha)$ dan didapatkan hasil nilai Cronbach's alpha 
yaitu; 1) Conditions for Community $\alpha=0.859$, 2) Meaning at Work $\alpha=0.858$, dan 3) Inner Life $\alpha=0.804$ yang artinya alat ukur yang dikembangkan oleh Ashmos \& Duchon ini telah reliabel. Skala likert digunakan pada kuesioner workplace spirituality. Lima alternatif jawaban diberikan pada masing-masing aitem favourable dan unfavourable dengan keterangan penilaian sebagai berikut:

Tabel 1. Penilaian Aitem

\begin{tabular}{ccc}
\hline Pilihan Jawaban & Skor Item Favourable & Skor Item Unfavourable \\
\hline Sangat Tidak Setuju & 1 & 5 \\
Tidak Setuju & 2 & 4 \\
Netral & 3 & 3 \\
Setuju & 4 & 2 \\
Sangat Setuju & 5 & 1 \\
\hline
\end{tabular}

Peneliti membagi jenjang nilai workplace spirituality menjadi tiga kategori yaitu, tinggi, sedang, dan rendah.

\section{Teknik Analisis Data}

Penelitian ini menggunakan teknik statistik untuk melakukan pengujian terhadap reliabilitas, validitas, normalitas, homogenitas dan hipotesis penelitian. Pengujian hipotesis dilakukan menggunakan uji Kruskal-Wallis untuk menguji perbedaan workplace spirituality ditinjau dari tingkat pendidikan dan lama bekerja di organisasi. Untuk menguji perbedaan workplace spirituality ditinjau dari jenis kelamin pria dan wanita digunakan uji beda atau t-test. Analisis dan pengolahan data penelitian dilakukan menggunakan bantuan program SPSS versi 24.

\section{Hasil}

\section{Uji Validitas dan Reliabilitas}

Butir-butir The Meaning and Purpose at Work Questionnaire yang digunakan telah diadaptasi dan diuji kesahihannya dengan nilai validitas aitem mulai dari $\mathrm{r}_{\mathrm{ix}}=$ 0,234 hingga 0.772 (Kaplan dan Saccuzzo, 2005). Kuesioner ini juga telah dinyatakan reliabel, ditunjukkan dengan nilai koefisien Cronbach's alpha $(\alpha)$ sebesar 0,945 . 


\section{Uji Normalitas dan Homogenitas}

Sebaran skor sebuah variabel penelitian dapat dikatakan mengikuti distribusi kurva normal jika harga p dari nilai K-S-Z lebih besar dari 0,05 (p > 0,05). Dengan menggunakan teknik One-Sample Kolmogorov Smirnov test, uji normalitas dilakukan terhadap distribusi skor workplace spirituality. Berdasarkan hasil uji normalitas, didapatkan hasil K-SZ $=0,079, \mathrm{p}=0,200$. Dengan demikian data skor total workplace spirituality dapat dinyatakan memiliki distribusi data yang normal.

Tabel 2. Hasil Uji Normalitas

One Sample Kolmogorov Smirnov Test

\begin{tabular}{ll}
\hline Test Statistic & .079 \\
\hline Asymp. Sig. (2-tailed) & .200 \\
\hline
\end{tabular}

*Signifikansi $\mathrm{p}>0,05$

Data penelitian dapat dikatakan homogen apabila memiliki nilai signifikansi lebih dari 0.05 ( $\mathrm{p}>0,05)$. Dengan menggunakan uji homogenitas yaitu Levene-test, didapatkan bahwa variabel workplace spirituality dengan jenis kelamin memiliki nilai $\mathrm{p}=0,624$. Variabel workplace spirituality dengan tingkat pendidikan memiliki nilai $\mathrm{p}=0,068$, dan variabel workplace spirituality dengan lama bekerja di organisasi memiliki nilai $\mathrm{p}=0,306$. Dengan demikian dapat disimpulkan bahwa varian kelompok memiliki data yang homogen, karena memiliki nilai signifikansi $\mathrm{p}>0,05$.

Tabel 3. Hasil Uji Homogenitas

\begin{tabular}{lc}
\hline \multicolumn{1}{c}{ Uji Homogenitas } & \multicolumn{1}{c}{ Nilai $\mathrm{p}$} \\
\hline WPS - Jenis Kelamin & .624 \\
\hline $\begin{array}{l}\text { WPS - Tingkat } \\
\text { Pendidikan }\end{array}$ & .068 \\
\hline WPS - Lama Bekerja & .306 \\
\hline
\end{tabular}

*Signifikansi $\mathrm{p}>0,05$

\section{Uji Hipotesis}

Pengujian hipotesis dilakukan dengan menggunakan uji analisis t-test dan Kruskal Wallis. Uji beda dilakukan terhadap perbedaan jenis kelamin dengan nilai $\mathrm{p}=0,287(\mathrm{p}>0,05)$. Nilai tersebut menunjukkan bahwa tidak terdapat perbedaan 
yang signifikan antara workplace spirituality pada karyawan pria dibandingkan dengan workplace spirituality pada karyawan wanita.

Tabel 4. Hasil Uji Beda

\begin{tabular}{clccc}
\hline & & \multicolumn{3}{c}{$t$-test for Equality of Means } \\
\cline { 3 - 5 } WPS & $\begin{array}{l}\text { Equal variances } \\
\text { assumed }\end{array}$ & -1.073 & 79 & Sig. (2tailed) \\
\hline & $\begin{array}{l}\text { Equal variances not } \\
\text { assumed }\end{array}$ & -1.044 & 30.989 & .287 \\
\hline
\end{tabular}

*Signifikansi $\mathrm{p}<0,05$

Data tingkat pendidikan dan lama bekerja di organisasi memiliki distribusi data yang tidak normal $(\mathrm{p}<0,05)$, oleh karena itu untuk melihat perbedaan workplace spirituality yang ditinjau dari tingkat pendidikan dan lama bekerja di organisasi, dilakukan analisis Kruskal Wallis. Berdasarkan hasil analisis, diketahui bahwa tidak terdapat perbedaan workplace spirituality ditinjau dari tingkat pendidikan karyawan, dengan nilai $\mathrm{p}=0,077(\mathrm{p}>0,05)$. Sedangkan untuk workplace spirituality ditinjau dari lama bekerja karyawan di organisasi, didapatkan nilai $\mathrm{p}=0,003$ $(\mathrm{p}<0,05)$ yang menunjukkan bahwa terdapat perbedaan workplace spirituality yang signifikan ditinjau dari lama bekerja karyawan di organisasi.

Tabel 5. Hasil Uji Kruskal Wallis

\begin{tabular}{lcc}
\hline & WPS-Pendidikan & WPS-Lama Bekerja \\
\hline Chi-Square & 5.126 & 11.644 \\
df & 2 & 2 \\
Asymp Sig. & .077 & .003 \\
\hline \multicolumn{2}{c}{ *Signifikansi $p<0,05$}
\end{tabular}

\section{Deskripsi Data}

Tabel 6. Hasil Kategorisasi Workplace Spirituality

\begin{tabular}{ccc}
\hline Kategori & Jumlah & Persentase \\
\hline Rendah & 0 & 0 \\
Sedang & 33 & $41 \%$ \\
Tinggi & 48 & $59 \%$ \\
\hline
\end{tabular}

Hasil kategorisasi menunjukkan tingkat workplace spirituality subjek tergolong Sedang sebesar 41\% (33 subjek) dan sebesar 59\% (48 subjek) menunjukkan tingkat workplace spirituality yang Tinggi. Skor rata-rata tiap varian 
kelompok berdasarkan lama bekerja karyawan di organisasi menunjukkan hasil skor mean untuk karyawan yang bekerja selama 1-10 tahun sebesar 37,92, skor mean untuk karyawan yang bekerja selama 11-20 tahun sebesar 56,36, dan skor mean untuk karyawan yang bekerja selama lebih dari 20 tahun sebesar 78,00.

\section{Pembahasan}

Workplace spirituality adalah tentang karyawan memahami bahwa dirinya merupakan makhluk spiritual yang jiwanya butuh untuk dipelihara di tempat kerjanya. Workplace spirituality terbentuk berdasarkan dimensi yang dianggap penting dalam pertumbuhan spiritual individu, yaitu inner life, a sense of connection and community dan meaning and purpose in work. Ketiga dimensi ini berhubungan langsung dengan diri individu.

Inner life dapat diartikan sebagai perasaan yang dimiliki individu tentang makna mendasar tentang siapa diri mereka. A sense of connection and community berhubungan dengan bagaimana individu menjalin relasi dengan orang lain pada lingkungan kerjanya. Menjadi bagian dari sebuah komunitas merupakan sebuah elemen yang penting dari perkembangan spiritual individu. Meaning and purpose in work berkaitan dengan keinginan individu untuk terlibat pada pekerjaan yang dapat memberikan makna terhadap hidupnya. Berdasarkan ketiga dimensi tersebut dapat dilihat bahwa faktor internal individu dapat mempengaruhi terbentuknya workplace spirituality.

Faktor demografi merupakan faktor yang melekat pada seseorang yang membedakan karakteristik individu satu dengan lainnya, termasuk di dalamnya adalah jenis kelamin, tingkat pendidikan, dan lama bekerja di organisasi. Dengan kata lain faktor demografi dapat menjadi gambaran dari faktor internal individu yang dapat mempengaruhi terbentuknya workplace spirituality pada masingmasing individu.

Spiritualitas bila dilihat melalui faktor individu seperti jenis kelamin, wanita dinilai memiliki tingkat spiritualitas yang lebih tinggi dibandingkan dengan pria (Khan \& Singh, 2013). Begitu juga dengan perilaku terkait tempat kerja, sensitivitas 
karyawan pria dan wanita terkait dengan spiritualitas dapat mempengaruhi komitmen kerja mereka (Indartono \& Wulandari, 2014).

Di sisi lain, pendidikan dianggap merupakan salah satu aspek yang dapat mendorong individu untuk dapat merasakan kehidupan yang bermakna (White, 2009). Latar belakang pendidikan yang baik dinilai dapat mempengaruhi keterampilan individu serta membentuk sumber daya psikologis individu sehingga individu dapat mempraktikkan perilaku-perilaku yang dinilai lebih sehat seperti memiliki kepercayaan diri dan kompetensi lain yang membantu individu dalam mengidentifikasi serta mencapai tujuan (Lawrence, 2017). Bila dikaitkan dengan konsep workplace spirituality tingkat pendidikan dapat mendorong individu untuk dapat merasakan meaning and purpose in work yang merupakan faktor pembentuk dari workplace spirituality. Berdasarkan penjelasan di atas, maka merupakan hal yang penting untuk mengetahui apakah terdapat perbedaan workplace spirituality ditinjau dari dua faktor individu yaitu jenis kelamin dan tingkat pendidikan.

Berdasarkan hasil uji hipotesis didapatkan bahwa tidak terdapat perbedaan workplace spirituality ditinjau dari jenis kelamin dan tingkat pendidikan. Hasil ini menunjukkan bahwa workplace spirituality yang dirasakan karyawan wanita tidak berbeda dengan workplace spirituality yang dirasakan oleh karyawan laki-laki, begitu pula dengan workplace spirituality pada karyawan yang memiliki latar belakang pendidikan SMA, S1 dan S2. Hasil ini menunjukkan bahwa tingkat spiritualitas yang dinilai lebih tinggi pada wanita tidak sama berlakunya dengan workplace spirituality yang dirasakan oleh karyawan.

Karyawan sebagai makhluk spiritual, memiliki inner life yang perlu untuk dipenuhi di tempat kerja. Hal ini tidak hanya berkaitan dengan kebutuhan fisik maupun intelektual, tetapi juga spiritual. Karyawan yang dapat mengerjakan pekerjaan yang sesuai dengan kemampuan dan tanggung jawabnya, serta dapat merasakan adanya dampak positif dari pekerjaan yang dilakukan ke lingkungan sekitarnya, akan membuat karyawan merasakan makna terkait pekerjaannya dan sekaligus merasa menjadi bagian dari tempatnya bekerja. Hal ini dapat dialami oleh karyawan secara luas dengan tidak membedakan jenis kelamin maupun tingkat pendidikannya. 
Dimensi terakhir sebagai pembentuk workplace spirituality yaitu a sense of connection and community dapat berkaitan erat dengan lamanya seseorang telah bekerja di organisasi. Individu akan semakin merasa menjadi bagian dari organisasi seiring dengan semakin lamanya ia bekerja di organisasi. Individu juga dapat semakin mengembangkan relasi dengan rekan kerja di lingkungan organisasi yang merupakan dasar dari pemenuhan kebutuhan spiritual individu. Hal ini akan membuat individu merasakan workplace spirituality.

Berdasarkan hasil uji hipotesis didapatkan bahwa terdapat perbedaan workplace spirituality yang dirasakan antara karyawan yang bekerja selama 1-10 tahun, 11-20 tahun, dan di atas 20 tahun. Hal ini dapat menunjukkan bahwa karyawan dengan masa kerja yang lebih lama pada sebuah organisasi akan semakin dapat merasakan keselarasan nilai pribadi dengan nilai-nilai organisasi yang dapat membuat karyawan merasakan workplace spirituality yang lebih tinggi. Hal ini juga memperkuat pernyataan Duchon \& Plowman (2005), yang menyatakan bahwa dengan memandang workplace spirituality sebagai sebuah iklim psikologis, individu dapat merasakan kehidupan internalnya terpelihara dengan pekerjaan yang bermakna dan dengan ditempatkan dalam konteks suatu komunitas. Dengan iklim kerja yang dapat memfasilitasi kebutuhan spiritual karyawan, karyawan dapat merasakan kecocokan atau kenyamanan dengan organisasi dan lingkungannya.

Organisasi merupakan tempat bagi individu untuk berkembang dan memenuhi kebutuhan spiritualnya. Seiring dengan meningkatnya masa kerja karyawan di organisasi, maka karyawan dapat merasakan keselarasan yang kuat antara nilai pribadi dengan misi dan tujuan organisasi. Hal ini dapat membuat karyawan merasakan keterikatan yang positif terhadap organisasi. Selain itu, karyawan dengan masa kerja yang lebih lama juga menunjukkan bahwa ia dapat merasakan makna penting dari pekerjaannya yang merupakan salah satu faktor dalam pembentukan workplace spirituality. Pada akhirnya individu dapat merasakan makna dan juga merasakan bahwa lingkungan kerjanya memiliki nilai yang selaras dengan nilai pribadinya yang berujung pada pemenuhan dari kebutuhan spiritual individu. Hal ini dapat menggambarkan bagaimana workplace 
spirituality dapat bergerak dan berubah sesuai dengan proses yang dialami oleh individu di pekerjaannya.

Konsep workplace spirituality menekankan bahwa terpenuhinya inner life dapat menjadi faktor pendorong bagi individu untuk dapat menjalankan outer life yang lebih produktif dan bermakna. Workplace spirituality pada diri karyawan dinilai dapat berpengaruh terhadap meningkatnya performa kerja organisasi, kepuasan kerja, komitmen kerja, serta tingkat turnover karyawan. Dengan memperhatikan aspek spiritualitas karyawan berarti organisasi bersedia untuk berupaya memberikan lingkungan kerja yang dapat memelihara kebutuhan spiritual karyawan yang pada akhirnya akan membuat karyawan merasakan kebermaknaan terkait pekerjaannya yang menjadi dasar bagi karyawan untuk dapat menampilkan perilaku kerja yang positif. Oleh karena itu penting bagi organisasi untuk mulai memberikan perhatian terhadap konsep workplace spirituality dalam praktik kerja organisasi.

\section{Simpulan dan Saran}

Terdapat perbedaan yang signifikan pada workplace spirituality ditinjau dari lama bekerja di organisasi. Rata-rata skor workplace spirituality yang tinggi dimiliki oleh karyawan yang telah bekerja selama lebih dari 20 tahun. Sedangkan bila ditinjau berdasarkan jenis kelamin dan tingkat pendidikan, tidak terdapat perbedaan workplace spirituality yang signifikan pada diri karyawan.

Hasil dari penelitian ini diharapkan dapat menjadi sebuah kajian baru bagi manajemen organisasi terutama untuk bagian Sumber Daya Manusia. Dengan mempertimbangkan manfaat dari workplace spirituality, aspek spiritualitas karyawan hendaknya dapat menjadi salah satu kajian baru yang perlu untuk dikembangkan bagi karyawan terutama bagi organisasi di Indonesia.

Selain itu, workplace spirituality merupakan sebuah konsep baru yang perlu untuk dilakukan penelitian lebih lanjut. Untuk penelitian selanjutnya, diharapkan jumlah Subjek yang dilibatkan dalam penelitian dapat lebih ditingkatkan serta penelitian dapat dilakukan pada berbagai organisasi yang berbeda agar dapat melihat gambaran yang lebih luas mengenai workplace spirituality. 
Workplace Spirituality ditinjau dari Aspek Demografi... 


\section{Daftar Pustaka}

Ashmos, D. P., \& Duchon, D. (2000). Spirituality at Work: A Conceptualization and Measure, 9(2), 134-145. https://doi.org/10.1002/job.583

Daft, R.L. 2008. Organization Theory and Design. Tenth Edition. United States: South-Western Cengage Learning

Duchon, D., \& Plowman, D. A. (2005). Nurturing the spirit at work: Impact on work unit performance. Leadership Quarterly, 16(5), 807-833. https://doi.org/10.1016/j.leaqua.2005.07.008

Houghton, J. D., Neck, C. P., \& Krishnakumar, S. (2016). The What, Why, and How of Spirituality in The Workplace Revisited: A 14-year Update and Extension. Journal of Management, Spirituality and Religion, 13(3), 177-205. https://doi.org/10.1080/14766086.2016.1185292

Indartono, S., \& Wulandari, S. Z. (2014). Moderation effect of gender on workplace spirituality and commitment relationship: case of Indonesian ethics. Asian Journal of Business Ethics, 3(1), 65-81. https://doi.org/10.1007/s13520-0130032-1

Jean, C., \& Garcia, Z. (2003). Workplace Spirituality and Organizational Performance. Public Administration Review, 63, No. 3(May/June), 355-363.

Kaplan, R.M dan Saccuzzo, D.P. 2005. Psychological Testing Principles, Application and Issue. Sixth Edition. USA: Wadsworth

Khan, I., \& Singh, N. (2013). A Study on Gender Differences on Gratitude , Spirituality and Forgiveness Among School Teachers. International Journal of Applied Science and Engineering, 1(1), 9-14.

Lawrence, E. M. (2017). Why Do College Graduates Behave More Healthfully Than Those Who Are Less Educated? Journal of Health and Social Behavior, 58(3), 291-306. https://doi.org/10.1177/0022146517715671

Milliman, J., Czaplewski, A. J., \& Ferguson, J. (2003). Workplace spirituality and employee work attitudes: An exploratory empirical assessment. Journal of Organizational Change Management, 16(4), 426-447. https://doi.org/10.1108/09534810310484172

Mitroff, I. I., \& Denton, E. A. (1999). A Study of Spirituality in the Workplace. Sloan Management Review, 83-91. Retrieved from http://strandtheory.org/images/Spirituality_in_the_workplace-

Mitroff_Denton.pdf

Sugiyono. (2015). Metode Penelitian Pendidikan (Pendekatan Kuantitatif, Kualitatif, dan R\&D). Bandung: Alfabeta.

Tecchio, E. L., Cunha, C. J. C. de A., \& Santos, F. B. (2016). Spirituality in organizations? Organizações \& Sociedade, 23(79), 590-608. https://doi.org/10.1590/1984-9230794

White, J. (2009). Education and A Meaningful Life. Oxford Review of Education, 35(4), 423-435. https://doi.org/10.1080/03054980902830134

Yogatama, L. A. M., \& Widyarini, N. (2015). Kajian Spiritualitas di Tempat Kerja pada Konteks Organisasi Bisnis. Jurnal Psikologi, 42(1), 1. https://doi.org/10.22146/jpsi.6939 